\title{
La educación preescolar vista a través de NO-DO (1943-1975): un proyecto benéfico-asistencial
}

The Pre-School Education through NO-DO (1943-1975): a Charity-Welfare Project

A educação pré-escolarvista através de NO-DO (1943-1975): um projeto benéfico-assistencial

María Dolores Molina-Poveda*

(iD) orcid.org/0000-0002-8535-9738

\section{Para citar este artículo}

Molina-Poveda, M. (2021). La educación preescolar vista a través de NO-DO (1943-1975): un proyecto benéficoasistencial. Revista Colombiana de Educación, 1(83), 1-20. https://doi.org/10.17227/rce.num83-10753.

Fecha de recepción: 22/11/2019

Fecha de evaluación: 27/08/2020

\section{(9) (1) @ 8}

* Doctora en Educación por la Universidad de Málaga, y graduada en Educación Infantil. Profesora de la Universidad Isabel y la Universidad de Málaga, España. Correo: mariadolores.molina.poveda@ui1.es 


\section{Resumen}

Palabras clave: educación

preescolar; NO-D0;

propaganda; guardería;

historia de la Educación
En 1939 se instauró en España la dictadura franquista, la cual intentó retornar a los valores e ideales tradicionales de España, entre los que primaba que la función de la mujer era el cuidado del hogar y de los hijos, mientras que la función del hombre era trabajar fuera de casa. Con estos planteamientos, la educación de los niños en edad preescolar no fue una prioridad para el régimen, a pesar de que había familias que necesitaban contar con instituciones donde sus hijos fueran atendidos mientras trabajaban. El Auxilio Social y las cajas de ahorros ofrecieron algunas soluciones de carácter benéficoasistencial proponiendo modelos de guarderías en las zonas rurales y obreras, en las que atendían a estos menores proporcionándoles los cuidados que las madres no podían, por tener que trabajar fuera del hogar. En este artículo de investigación se pretende analizar la imagen de guarderías y hogares infantiles que ofrecían el método NO-DO, un medio propagandístico audiovisual del régimen creado a finales de 1942. A pesar de que en sus inicios el número de noticiarios y reportajes proyectados sobre estos espacios escolares fueron escasos, aunque a partir de la década de los sesenta estos comenzaron a aumentar debido a que el número de mujeres trabajadoras aumentó y el régimen comenzó a verlo como una necesidad social. Además, en las noticias y documentales sobre estos centros se destacaba, como era de esperar, que los niños eran atendidos en las mejores condiciones y según "las normas pedagógicas más avanzadas" entre las que primaba el juego.
Keywords: early childhood

education; NO-DO;

propaganda; nursery schools;

history of education

\section{Abstract}

In 1939 the Franco dictatorship was established in Spain, which tried to return to the traditional values and ideals of Spain, among which the role of women was the home and the care of children, while the role of men was to work outside the home. With these approaches, the education of pre-school children was not a priority for the regime, although there were families that needed institutions where their children were cared for while working. Auxilio Socialand Cajas de Ahorros offered some charitable-type solutions. Assistance such as day-care centers in rural and working-class areas to care for these children by providing them with the care that mothers could not give them because they had to work outside the home. This article analyzes the image of these nurseries and children's homes offered by NO-DO, the audiovisual propaganda medium of the regime created at the end of 1942. Although the number of news and reports projected on these school spaces was scarce, from the 1960s these began to increase because the number of working women increased and the regime began to see it as a reality that was previously denied. In addition, the news and documentaries about these centers highlighted, as expected, that the children were cared for in the best conditions and according to "the most advanced pedagogical standards" among which play prevailed.

\section{Resumo}

Em 1939, instaurou-se em Espanha a ditadura franquista que tentou regressar aos valores e ideais tradicionais de Espanha, entre os quais se salientava que a função da mulher era o lar e o cuidado dos filhos, enquanto a função do homem era trabalhar fora de casa. Com estas abordagens, a educação das crianças em idade pré-escolar não foi uma prioridade para o regime, embora, houvesse famílias que necessitavam contar com instituições onde seus filhos fossem atendidos quando trabalhavam. 0 Auxilio Social e as Caixas Económicas ofereceram algumas soluções de caráter beneficente-assistencial como a criação de creches nas zonas rurais e operárias nas quais atenderam a os menores proporcionando-Ihes os cuidados que as mães não podiam dar-Ihes por ter que trabalhar fora do lar. Este artigo analisa a imagem que estas creches e lares infantis ofereciam NO-DO, o meio de propaganda audiovisual do regime criado no final de 1942. 0 número de noticiários e reportagens projetados sobre estes espaços escolares foi escasso, embora a partir da década de sessenta estes começaram a aumentar porque o número de mulheres trabalhadoras aumentou e o regime começou a vê-lo como uma realidade que antes negava. Além disso, nas notícias e documentários sobre estes centros destacava-se, como era de esperar, que as crianças eram atendidas nas melhores condições e segundo "as normas pedagógicas mais avançadas" entre as quais o jogo primava. 
La educación preescolar vista a través de no-do (1943-1975): un proyecto benéfico-asistencial | María Dolores Molina-Poveda

\section{Introducción}

La educación infantil constituye hoy el primer nivel del sistema educativo español y está divido en dos ciclos: el primero comprende desde los cero hasta los tres años y el segundo abarca desde los tres hasta los seis años. Sin embargo, el carácter educativo de esta etapa en España no está implantado en su totalidad, a pesar de los avances logrados desde que el segundo de ellos se declaró gratuito, aunque no obligatorio (Sanchidrián, 2009). Batres (2016) expone los resultados del informe elaborado por la Comisión Europea en 2011 y en 2014 en los que destaca que la división de la educación infantil en dos ciclos hace que el primero sea visto como un periodo asistencial, es decir, un periodo de cuidado del bebé-niño que tiene que ser atendido por una persona ajena a su familia porque sus padres están trabajando. Además, Batres destaca que esta concepción hace que el segundo ciclo sí sea visto con carácter educativo y que recaiga sobre este todo el componente pedagógico que debería, no obstante, recaer en los seis años que componen la educación infantil y no solamente en los tres últimos. Para comprender el motivo que ha llevado a este nivel educativo a ser visto así, es necesario conocer su historia en España y especialmente su desarrollo durante la etapa donde se sitúan los años de estudio de este artículo (1943-1975).

La primera escuela de párvulos fue inaugurada el 10 de octubre de 1838 en Madrid (Sanchidrián, 1991), aunque hasta esa fecha algunas niñas y niños de entre tres y siete/ocho años asistían a las "escuelas de amigas". Estas eran "escuelas particulares, regidas por alguna señora que por un pequeño estipendio recogía niñas [...], a las que les enseñaba las cuatro tablas, las oraciones religiosas más importantes y, también, a coser" (Ruiz, 2010, p. 94), aunque en contadas ocasiones les enseñaban a leer y a escribir, ya que la mayoría de las maestras carecían de estos conocimientos. La primera escuela de párvulos fue creada por la Sociedad Encargada para Propagar y Mejorar la Educación del Pueblo (SEPMEP). Esta sociedad fue creada con carácter público y finalidad benéfica y se le encargó la creación de escuelas de párvulos con el fin de aumentar el nivel cultural de la población y de solucionar el problema social creado por la industrialización. Pablo Montesino fue miembro de la comisión de dicha sociedad y el responsable de redactar un manual (1840) para orientar a los futuros maestros de estas escuelas acerca de los objetivos, fines, organización, contenidos, etc., de las mismas.

Carmen Sanchidrián (2015) expone que la educación de párvulos puede dividirse en tres etapas: desde 1838 hasta que se comenzó a introducir la metodología de Froebel (1874); desde 1874 hasta 1970/1975 (promulgación de la Ley General de Educación/final del franquismo) que se caracterizó por ser un periodo muy largo en el que se produjeron nuevos ensayos de las metodologías de Montessori y Froebel y el surgimiento de un movimiento en Cataluña que incorporó planteamientos de la Escuela Nueva, aunque el inicio del franquismo supuso el freno a todas estas pedagogías que, a partir de la década de los sesenta, comenzaron a retomarse; y la tercera etapa abarca desde 1970/1975 hasta nuestros días.

Un hecho a destacar es que fue en las escuelas de párvulos donde se hizo el primer intento serio de reforma de la enseñanza pública, enfatizando lo "educativo" sobre lo meramente "instructivo", renovando las teorías y los métodos y adoptando los más "vanguardistas". (Sanchidrián, 1991, p. 85).

No obstante, los intentos por renovar la educación de párvulos, como los relativos a todos los niveles del sistema educativo, se vieron interrumpidos por la instauración de la dictadura franquista en 1939 tras una guerra civil que dejó el país muy mermado, produjo la interrupción y el retroceso de la modernización y el progreso que había vivido España durante las primeras 
La educación preescolar vista a través de no-do (1943-1975): un proyecto benéfico-asistencial | María Dolores Molina-Poveda

décadas del siglo xx y, sobre todo, en la Segunda República. Esta vuelta al pasado y la alianza entre Iglesia y Estado se tradujeron en el inicio del nacionalcatolicismo y en la supresión del modelo educativo republicano (las innovaciones introducidas, el laicismo y la coeducación). Hasta la década de los sesenta, "la atención educativa a los más pequeños se redujo a actuaciones benéfico-asistenciales que se concretaban en la creación de casas cuna, guarderías y parvularios", aunque a partir de esta década se volvió a iniciar el proceso de renovación pedagógica "aprovechando las iniciativas educativas privadas en las que existía un mayor espacio de libertad y, en el caso de las escuelas infantiles, aprovechando la escasa atención del Estado a este nivel educativo" (Sureda, 2010, p. 260).

Jordi Monés (1991) destaca que, desde que finalizó la Guerra Civil hasta la década de los 60, la educación de párvulos es un proceso que resulta difícil de estudiar si lo enmarcamos dentro de la educación reglada o educación formal. Esta situación estaba propiciada por la doctrina del nuevo régimen que consideraba esta etapa como voluntaria al ser una función que debía desarrollar la madre en el ámbito familiar (Monés, 1991; Valiente, 2010). Si a este hecho se le agregan las restricciones económicas de las primeras décadas del franquismo, la escasa demanda de estos servicios y el interés del Estado por otros niveles educativos (Valiente, 2010), se podría justificar la "casi nula inversión del Estado en este ciclo escolar, dejándolo prácticamente en manos de la iniciativa privada que cubría, sólo en parte, la demanda generada en este terreno" (Monés, 1991, p. 155).

La Ley de 17 de julio de 1945 sobre Educación Primaria estableció que dicho nivel educativo estaba dividido en una serie de periodos: periodo de iniciación, periodo de enseñanza elemental (6-10 años), periodo de perfeccionamiento (10-12 años) y periodo de iniciación profesional (12-15 años). En este caso, nos vamos a centrar en el periodo de iniciación por ser el que se corresponde con la educación de párvulos. Este periodo, a su vez, estaba dividido en escuelas maternales (hasta los 4 años) y escuelas de párvulos (de los 4 a los 6 años). Según el artículo 19 de dicha legislación, "las Escuelas maternales y de párvulos serán creadas en los núcleos de población que permitan matrícula suficiente", además de ser obligatorias en las zonas agrícolas o industriales donde "el trabajo condicionado de la madre exija el cuidado y custodia inteligente de los niños menores de seis años". Además, "su instalación, disciplina y desenvolvimiento reflejarán la vida de: hogar, limpia, cuidada y alegre", y los conocimientos que estas escuelas transmitían no tenían que exceder "nunca de aquellas experiencias y prácticas formativas propias de la psicología y corta edad de los párvulos". Las escuelas de párvulos podían admitir indistintamente a niñas y a niños cuando la matrícula no permitiese la división por sexos (artículo 20), el profesorado era exclusivamente femenino (artículo 21).

La educación de párvulos fue uno de los niveles educativos a los que el Estado prestó poca o nula atención hasta la década de los 60-70, aunque Valiente destaca que la "élite gubernamental no consideró en ningún momento que la falta de plazas en educación preescolar constituyera un problema acuciante que el Estado había de resolver" (2010, p. 248), a pesar de que existían ciertas demandas de este servicio por parte de la sociedad española, sobre todo en aquellas zonas donde el trabajo femenino era mayor. En este periodo se produjo un hito para la educación de párvulos y fue la promulgación de la Ley General de Educación (1970). Esta ley cambió el nombre de este nivel educativo por el de educación preescolar, además de establecer, por primera vez, esta etapa como un nivel no obligatorio y gratuito (en los centros estatales) del sistema educativo.

En esta investigación vamos a analizar qué mostró el Noticiario Cinematográfico Español (NO-DO, acrónimo de noticiarios y documentales) sobre las escuelas de párvulos, guarderías y hogares infantiles creados por Auxilio Social y por las cajas de ahorros, desde 1943 hasta 
1975, como entidades benéfico-asistenciales. El nuevo Estado necesitaba "constituirse como una máquina con los engranajes dispuestos para cumplir una función primordial: justificar su propia existencia ante la opinión" (Martín, 2006, p. 15). La prensa, tanto escrita como audiovisual, fue su principal pilar para lograr que la sociedad asumiese que la nueva política era la correcta. NO-DO nació a finales de 1942 ante la creciente necesidad del régimen de disponer de un medio audiovisual propagandístico con el que informar a los españoles sobre las noticias nacionales e internacionales que, bajo su doctrina, debían conocer.

Según la Orden de 17 de diciembre de 1942, NO-DO gozó de exclusividad y su emisión fue obligatoria en todos los locales cinematográficos de España hasta 1975 (Orden de 22 de agosto de 1975), aunque continuó proyectándose en algunos cines hasta 1981. Su finalidad, atendiendo a Joaquín Soriano - primer director de NO-DO-, era reflejar los "aspectos nobles" de España y del mundo entero con el objetivo de "informar, instruir y recrear" a toda la población y de, como rezaba su eslogan, poner "el mundo entero al alcance de todos los españoles" (Tranche y Sánchez, 2018, pp. 259-260). NO-DO, como producto del cine, abordó la realidad desde la perspectiva del entretenimiento y no tanto desde la información o la persuasión, "de ahí que los contenidos políticos ocuparan sólo una parcela dentro de la variedad de temas proyectados que, generalmente, eran livianos" (Rodríguez Mateos, 2008, p. 25) (curiosidades, cultura, educación, deportes, variedades, moda, ocio, etc.). Todos estos temas fueron mostrados como tópicos recurrentes en los diferentes números de NO-DO. No obstante, la llegada de la televisión hizo tambalear los cimientos de esta entidad, pues ya no gozaba de exclusividad y la inmediatez que ofrecía este nuevo medio lo convertía en más atractivo para los espectadores.

\section{Metodología}

En esta investigación hemos utilizado como fuente principal NO-DO (1943-1981) para conocer que transmitió este organismo, desde 1943 hasta 1975, sobre la educación preescolar impartida en las escuelas de párvulos, las guarderías y los hogares infantiles fundados por Auxilio Social y las cajas de ahorros en su labor benéfico-asistencial. De esta forma, pretendemos reconstruir una parte de nuestro pasado a través de uno de los medios audiovisuales más longevos y que tuvo un papel relevante en la construcción de la memoria histórica, colectiva y social. Para ello hemos recurrido al método histórico, ya que

la historia es la disciplina que estudia e intenta reconstruir sobre criterios epistemológicos de veracidad los hechos acaecidos al ser humano en épocas precedentes, tomando como base diversas fuentes e instrumentos que le permiten acceder al conocimiento de lo pretérito. (Hernández, 2012, p. 15).

Esta fuente, al ser un medio propagandístico, requiere de la utilización de otras fuentes complementarias, pues la proyección de una sola realidad, en este caso la del régimen, podría convertir esta fuente en poco fiable. Por otra parte, aunque las imágenes estuviesen edulcoradas para transmitir una realidad, siempre es posible extraer de ellas información sobre el tema tratado, pues, como indican Paz y Sánchez:

la existencia de falsificaciones o el hecho de que los noticiarios escamoteen en ocasiones la realidad ingrata e intenten sustituirla por otra más deseable no disminuyen su significación testimonial, [pues] las reconstrucciones que se incluyen en todas las actualidades cinematográficas tienen el valor de ofrecer una interpretación determinada de un suceso, que ilustra las características de la época. (1999, p. 20) 
En 2011, se autorizó la publicación y comercialización de los fondos de NO-Do en la intranet. Para ello se creó, dentro de la web de Radiotelevisión Española (RTVE), la página web de Filmoteca Española, donde se han publicado y difundido todos los números que componen el archivo de NO-DO. Esta digitalización y difusión de los contenidos nos ha permitido acceder a ellos sin la necesidad de trasladarnos hasta el archivo para visionar y extraer la información. NO-DO, según la página web de Filmoteca Española, está formado por cinco secciones propias (Noticiarios ${ }^{1}$, Documentales en Blanco y Negro, Documentales en Color, Revista de Imágenes e Imágenes del Deporte) más dos secciones con material producido por otras entidades y adquirido por NO-DO. De esos apartados, solo vamos a analizar los números de las secciones propias de NO-DO.

En total, hemos hallado 15 números $^{2}$ repartidos en las secciones de Noticiario, Documentales en Color y Revista de Imágenes. La información extraída de cada número ha sido recogida en una ficha de observación para facilitar su análisis posterior. Los apartados que componen la ficha son sección de no-do (Noticiarios, Documental en Blanco y Negro, Documental en Color, Revista de Imágenes e Imágenes del Deporte), número y fecha de publicación del número cinematográfico, minuto en el que aparece la escena educativa, nombre de la institución donde se desarrolla la escena y ubicación, descripción de todo lo que acontece en la escena educativa y voz en off.

\section{Resultados}

El régimen franquista instaurado en España en 1939, tras la victoria del bando nacional en la Guerra Civil, tuvo como consecuencia que, hasta finales de la década de los cincuenta, España viviese inmersa en un periodo caracterizado por la autarquía, el aislamiento internacional y la represión. Además, se implantaron medidas para que la mujer, una vez casada y salvo en contadas excepciones, no pudiese acceder al mercado laboral, lo que supuso la no demanda de centros de párvulos, pues la educación de los menores de seis años era una función de las madres. "La separación nítida entre la esfera doméstica-reproductiva y la esfera públicaproductiva que favorece el modo de producción industrial va a hacer posible la concreción y visualización del papel de ama de casa" (Roca, 2005, p. 86). Sin embargo, el régimen no podía cerrar los ojos ante la existencia de madres trabajadoras que o llevaban a sus hijos a los centros de párvulos o los dejaban con sus hermanos mayores obligando a estos a no poder asistir al colegio. Desde finales de los años cincuenta se inició un periodo de apertura hacia el exterior, de desarrollo industrial, de recuperación económica y de migración de las zonas rurales a las industriales.

Los avances y la apertura hacia el exterior acaecidos a finales de los años 50 continuaron en las décadas de los 60 y de los 70 debido, fundamentalmente, a la promulgación en 1959 del Plan de Estabilización y de los tres planes de Desarrollo Económico y Social ejecutados, respectivamente, en 1964-1967, 1968-1971 y 1972-1975. La migración de las zonas rurales a las industriales hizo que España se convirtiese en un país semiindustrial, que aumentase la clase media y que el tipo de familia española evolucionase de la familia rural en la que predominaban la jerarquía, el trabajo familiar y la autoridad, a la familia urbana en la que se

1 La sección Noticiarios fue la más importante dentro de NO-DO llegando a crearse una segunda edición a partir del Noticiario n. ${ }^{\circ} 20$ (A y B) (1943) y una tercera (A, B y C) entre 1960-1967, aunque a partir de este año volvieron a editar dos ediciones (A y B).

2 NO-D0 emitió otras noticias y documentales sobre centros donde se impartía la educación de párvulos o preescolar, aunque en este estudio solo nos vamos a centrar en los impulsados por Auxilio Social y las cajas de ahorros. Esta entidad emitió 12 números más donde informaban sobre guarderías, jardines de infancia, etc. 
intentó suavizar el carácter patriarcal (Carreño, 2002). La introducción de los electrodomésticos en el hogar y el "inicio de la sociedad de consumo" caracterizado por un "consumo femenino y familiar impulsaron un nuevo modelo de ama de casa denominado 'ingenieras del hogar'" (Roca, 2005, p. 92). Esta adquisición de nuevos bienes propició el trabajo extradoméstico femenino favoreciendo que el porcentaje de mujeres activas experimentase una subida de seis puntos en la década de los sesenta, lo que supuso más del doble si lo comparamos con la situación laboral femenina en los años cincuenta (Roca, 2005).

NO-DO permitió "la educación popular de una ciudadanía con una formación que no sobrepasaba la del nivel escolar", ya que el "cine copaba la atención de los españoles de aquellos difíciles años" (Rodríguez Martínez, 1999, p. 10). Joaquín Soriano destacaba que NoDo despertó un gran interés entre el público femenino, y es que el primer director de esta entidad alegaba que su objetivo era provocar la "máxima sorpresa del espectador", ya que NO-DO "no es más que un periódico cuyo mayor porcentaje de lectores se encuentra en el público femenino; de ahí que dediquemos un especial interés en hacerlo ameno a las mujeres" (Tranche y Sánchez, 2018, p. 107).

Para hacerlo más ameno para las mujeres, primó la proyección de las noticias sobre temas banales, al ser las que más interés despertaban en el sexo femenino. Además, el índice de analfabetismo era mayor entre las mujeres, lo que propició que No-Do fuese el medio más idóneo para propagar, de forma directa e indirecta, las actitudes, normas sociales, identidades y valores establecidos por el régimen y que las mujeres debían adoptar y cumplir. Este papel asignado a la mujer como ama de casa, esposa, madre y buena cristiana fue el impulsado por este medio propagandístico. No obstante, a partir de la década de los sesenta no solo se produjo un aumento de noticias y documentales sobre la infancia, sino también sobre la mujer trabajadora y su formación (Molina, 2020; Molina y Sanchidrián 2020).

\section{La labor benéfico-asistencial impulsada por las}

\section{cajas de ahorros en favor de la infancia}

En España, existieron diversos organismos que fundaron centros de párvulos con carácter asistencial entre los que están las cajas de ahorros y los Montes de Piedad que, en su afán por eliminar la usura y por incluir a todas las clases sociales, reservaban una parte de sus beneficios a la educación, la sanidad, la cultura, etc. En el Decreto de 17 de octubre de 1947, se establecía que la actuación benéfica de esta institución era "complementaria a la del Estado en los campos de: creación y mantenimiento de instituciones sanitarias (dispensarios, sanatorios antituberculosos, colonias escolares, etc.); promoción y dotación de instituciones culturales (escuelas profesionales, bibliotecas, etc.) y construcción de viviendas protegidas" (Martínez, 2014, p. 270). La Orden de 26 de octubre de 1948 definió como obra social propia de las cajas todas aquellas instituciones costeadas y administradas directamente por ellas.

NO-DO emitió un reportaje en el n.0 889 (01/01/1962) de la sección Revista de Imágenes, y dos documentales en la sección Documentales en Color titulados Por los hombres del mañana (01/01/1968) y Míster Rosemberg visita España (01/01/1973) en los que mostraron algunas de las instituciones benéfico-asistenciales fundadas por las cajas de ahorros de las diferentes provincias de España y entre las que destacaron las guarderías. El número 889 de Revista de Imágenes (01/01/1962) informaba sobre algunas obras destinadas a la infancia e impulsadas por las cajas de ahorros. Entre ellas destacaba la Casa del Niño de Bermeo. Esta era una guardería donde las madres trabajadoras dejaban a sus hijos al cuidado de religiosas que les 


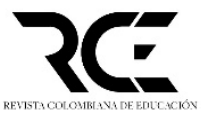

alimentaban y educaban poniendo a su disposición juegos (ábaco, columpios, casas de muñecas, coches...) y distracciones. A las niñas más mayores les enseñaban a coser a máquina (figura 1). En el documental Míster Rosemberg visita España (01/01/1973) se presentó el Colegio Nacional de la Sagrada Familia de Málaga. Dentro de este complejo también había una guardería donde los niños se desarrollaban en las condiciones ideales gracias al juego y al clima de esta localidad. Los niños estaban atendidos por "religiosas, maestras y personal especializado en puericultura" que favorecían el juego como "método infalible" para aumentar la motivación hacia la enseñanza (Documental en Color Por los hombres del mañana, 01/01/1968).

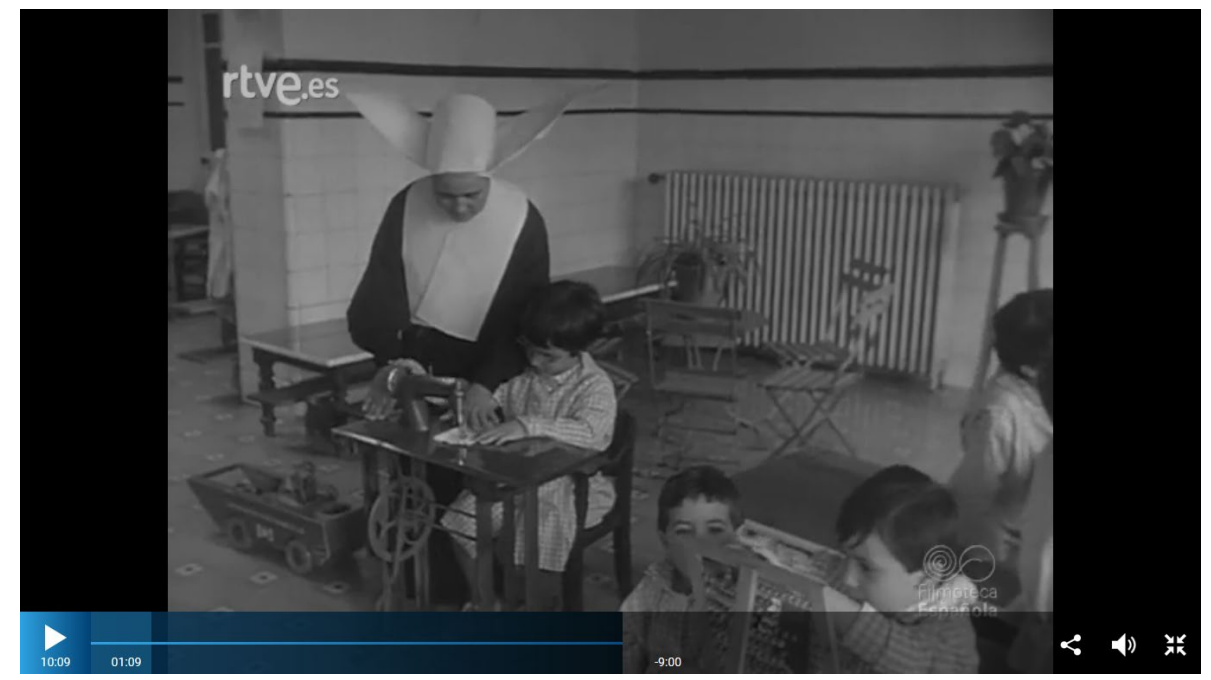

Figura 1. Niña de la casa del niño de Bermeo aprendiendo a coser a máquina. Fuente: (CFilmoteca Española y RTVE (2019. Tomada de Revista de Imágenes n. $0889(01 / 01 / 1962)$.

Otra guardería presentada en la sección de Documentales en Color (Por los hombres del mañana, 01/01/1968; Míster Rosemberg visita España, 01/01/1973) fue la construida en Benaoján (Serranía de Ronda). En ella, un grupo de religiosas cuidaban a una media diaria de 150 niños proporcionándoles las atenciones, el afecto, el cariño y los mimos que sus madres no podían darles cuando estaban trabajando en la industria chacinera. Esta guardería se complementaba con un colegio de párvulos donde continuaba la labor asistencial de la obra. Como se puede comprobar en los números de NO-DO explicados, las guarderías y los centros de párvulos estaban regentados por congregaciones religiosas femeninas, destacando el carácter católico implantado por el régimen franquista. En el documental titulado Míster Rosemberg visita España (01/01/1973) se mostró la guardería Virgen del Rosario, construida por la Caja de Ahorros de Jaén, en la que los niños cumplían "una etapa preescolar y de convivencia, en la que los juegos, muchos ya de carácter educativo, [tenían] un encaje adecuado". El juego era otro aspecto que caracterizaba estas guarderías. El niño aprendía a relacionarse con sus compañeros mientras aprendía jugando. 
La educación preescolar vista a través de no-do (1943-1975): un proyecto benéfico-asistencial | María Dolores Molina-Poveda

\section{La obra de protección al niño con familia de Auxilio Social: las guarderías y jardines maternales}

NO-DO tendió a mostrar en sus noticiarios y documentales la figura de Franco, así como los símbolos y mitos que giraban en torno al franquismo (Tranche y Sánchez, 2018), aunque también presentó noticias banales y aquellas que estaban relacionadas con la "gran" labor llevada a cabo por el régimen en pro de la sociedad, como, por ejemplo, una de sus obras más emblemáticas que estuvo centrada en el cuidado, la atención, la acogida y la protección de los más pequeños con o sin familia: la obra de Auxilio Social. Esta organización, inicialmente denominada Auxilio de Invierno, fue creada por Mercedes Sanz Bachiller y Javier Martínez de Bedoya en 1936, quienes se basaron en la Winterhilfswerk (WHW) alemana para fundarla y establecer cuál era su misión: dar alimento y ropa de abrigo a la población durante la contienda (Orduña, 1996). En 1937 cambió su denominación a Auxilio Social. El fin de la guerra hizo que las prioridades del régimen cambiasen, al igual que las necesidades de la población, por lo que esta institución tuvo que adecuarse a ellas y centrarse en, según las palabras pronunciadas por Carmen de Icaza (secretaria nacional de Auxilio Social cuando finalizó la guerra), trabajar todos juntos para vencer la ignorancia y la miseria, la enfermedad, la mortalidad infantil y la delincuencia, así como para fomentar y ensalzar la educación religiosa y política según el nacionalsindicalismo en todos los ámbitos y momentos de la vida, no solo en las aulas (Sánchez, 2008).

Este fin se pretendía alcanzar a través de tres secciones englobadas dentro de la Obra de Protección a la Madre y al Niño: protección a la madre, protección al niño con familia y protección al niño huérfano o abandonado. A su vez, cada departamento estaba compuesto por una serie de centros y hogares, aunque en este estudio nos vamos a centrar en las guarderías y jardines maternales de la sección de protección al niño con familia y en los hogares infantiles de la sección de protección al niño huérfano o abandonado. Las guarderías (niños de 0 a 3 años) y los jardines maternales (niños de 3 a 7 años) eran centros destinados al cuidado de los niños de madres trabajadoras y estaban ubicados en barrios obreros y zonas rurales (Pérez, 2010). Su fin, según el noticiario n.0 39A (27/09/1943) y el n. ${ }^{0} 611$ de Revista de Imágenes (01/01/1956), era proporcionar a los niños toda clase de cuidados y convertirlos en personas sanas y fuertes. Estos cuidados estaban centrados en la higiene (duchas, lavado de manos...), la atención médica (cada institución disponía, según el locutor, de un despacho médico), la alimentación, el juego y la gimnasia. Además, los niños recibían instrucción religiosa para fortalecer el alma. NO-DO emitió 10 números sobre guarderías y jardines maternales en la sección de Noticiarios y de Revista de Imágenes. El noticiario n. 0 815A (18/08/1958) informó sobre la guardería y el jardín maternal construidos en Castellón de la Plana en los que albergaban a cien niños de entre tres y siete años. El número 611 de Revista de Imágenes (01/01/1956) ampliaba esta información al explicar que los 110 niños y niñas de la guardería de Tarrasa permanecían "separados en distintas secciones según la edad y los cuidados que [necesitasen]" (los datos aportados eran muy generales y extrapolables al resto de este tipo de centros).

"Auxilio Social ha extendido por toda España la red de sus admirables instituciones entre las cuales [figuraban] guarderías infantiles [...] donde los pequeños, durante el periodo de trabajo de las madres, [eran] recibidos y atendidos cuidadosamente" (Revista de Imágenes n. ${ }^{\circ}$ 611, 01/01/1956). En el número citado apreciamos como intentaban transmitir a las madres un mensaje de tranquilidad, pero no solo con la palabra, sino también con las 
imágenes, al presentar escenas de los niños asistidos en la guardería de Tarrasa jugando, siendo cogidos por las cuidadoras mientras les dispensaban muestras de cariño y afecto (figura 2), duchándolos (figura 3), jugando con ellos en el jardín mientras recibían los beneficios del sol y comiendo apetitosos platos para crecer fuertes y sanos. En otra noticia insisten en que las madres trabajadoras desempeñaban su trabajo correctamente gracias a estas instituciones, pues sabían que sus hijos estaban bien atendidos "según las normas pedagógicas más avanzadas" (Revista de Imágenes, La semilla: una obra de Auxilio Social, 01/01/1965), volviendo a reforzar estas afirmaciones con las imágenes.

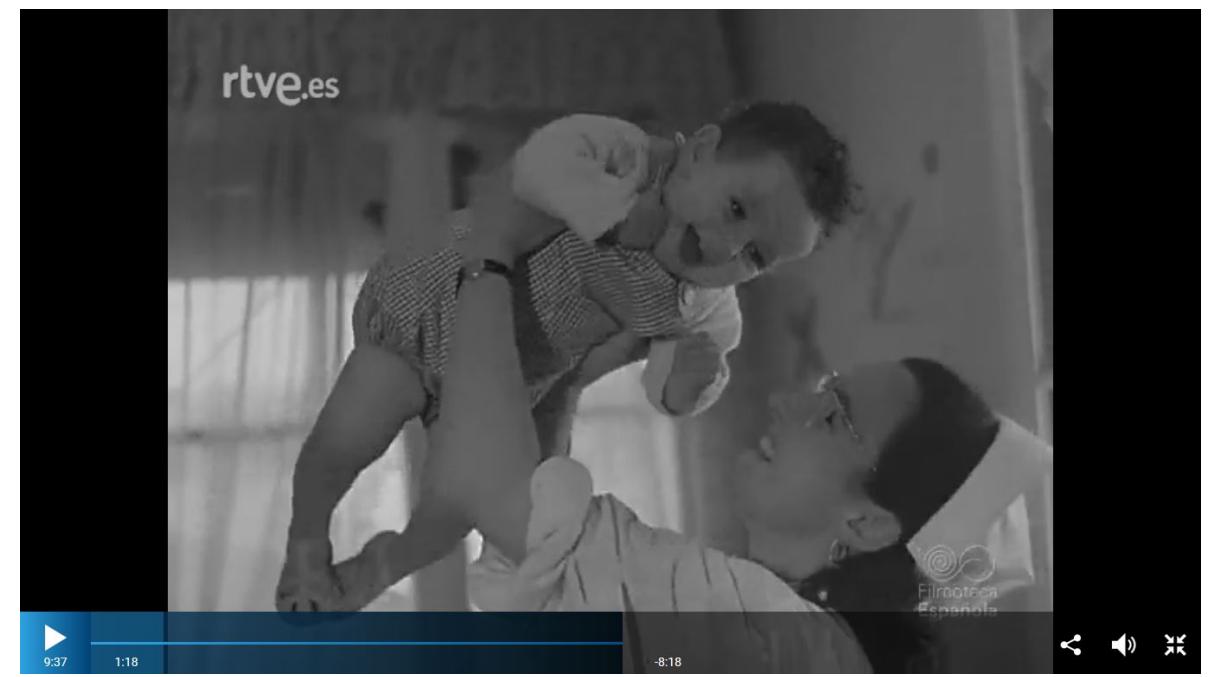

Figura 2. Cuidadora de una guardería (Tarrasa) de Auxilio Social cogiendo a un niño en brazos y jugando con él. Fuente: (C)Filmoteca Española y RTVE (2019). Tomada de Revista de Imágenes n.o 611 (01/01/1956).

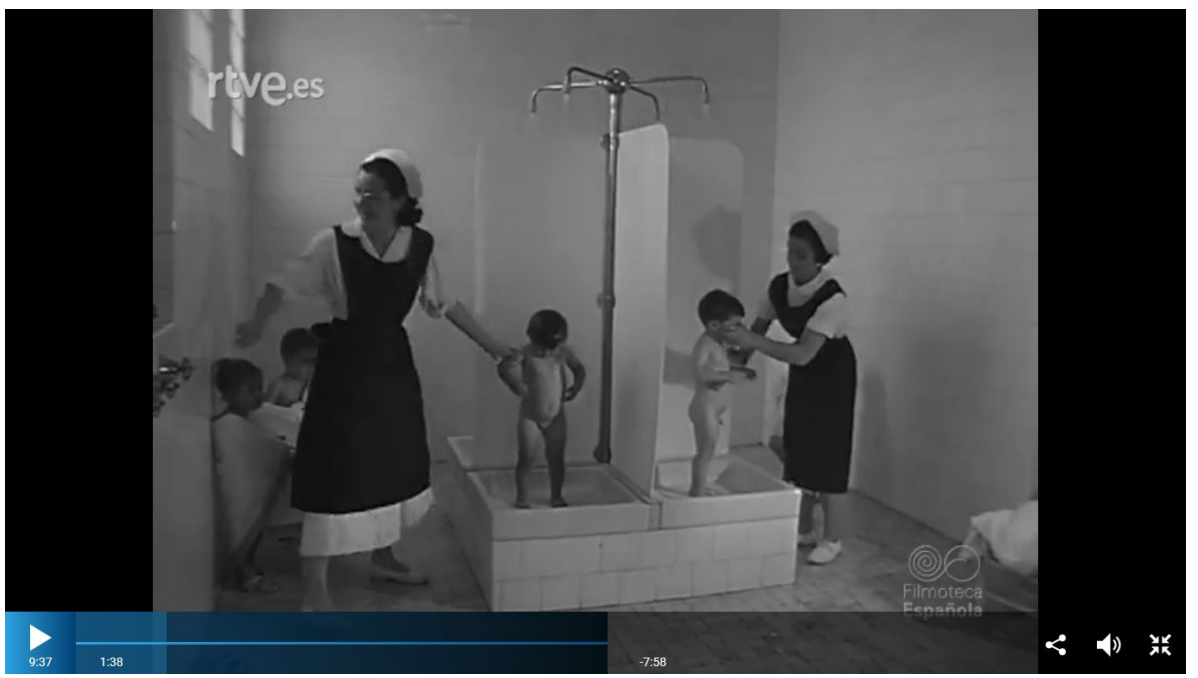

Figura 3. Cuidadoras de la guardería de Tarrasa duchando a los niños. Fuente: (C)Filmoteca Española y RTVE (2019). Tomada de Revista de Imágenes n. 611 (01/01/1956).

Estas pedagogías más avanzadas no aparecían explicadas en ningún número, pero sí encontramos, de forma general, las actividades que se ponían en práctica con los niños: "Valorar las cosas buenas y bellas, a concretar las primeras ideas que [bullían] en sus 
cabecitas, se les [enseñaba] a trazar los primeros palotes, y también a refrescar sus cuerpecitos cuando el calor [era] agobiante" (Revista de Imágenes, La semilla: una obra de Auxilio Social, 01/01/1965). En otra noticia se enfatizaba que el juego era la máxima ilusión de los niños y que estos jugaban felices en los albergues o en los jardines (Revista de Imágenes n. $\left.{ }^{\circ} 611,01 / 01 / 1956\right)$. Volvemos a encontrar una mención al juego y, por tanto, a su importancia en las guarderías y jardines maternales en el noticiario n. ${ }^{\circ} 546$ A (22/06/1953), donde la voz en off resaltaba los juegos y diversiones de los pequeños. Las imágenes solían ser sobre la vida del centro, de las dependencias y, sobre todo, de los juegos infantiles, ya fuesen en el jardín o en una sala. Los más pequeños jugaban en parques con muñecos y los más mayores lo hacían con triciclos, caballos de madera, muñecos.

Sánchez (2008) expone que las actividades pedagógicas que se ponían en práctica en los jardines maternales durante los primeros años (3-5 años) eran ejercicios corporales, ejercicios de activación sensorial, afanes lúdicos, adquisición de hábitos elementales e iniciación religiosa, y como medio didáctico se recurrían a los juegos montessorianos, decrolyanos y frobelianos. Para los niños de 5 a 7 años la maestra preparaba ejercicios de actividad sensorial, juegos educativos, ejercicios sensoriales, desenvolvimiento del sentido rítmico, narración de cuentos, dibujo y trabajos manuales, canto, iniciación religiosa e iniciación al lenguaje y al cálculo. Todo ello lo asimilaban a través de juegos de los pedagogos citados, pero también a través de la memorización. Las escenas que NO-DO mostraba en sus noticiarios eran breves y los planos solían ser generales, es decir, abarcaban casi toda la clase, por lo que resulta difícil deducir que materiales estaban utilizando los niños. No obstante, en algunas escenas de las noticias los vemos sentados por grupos y a cada uno realizando una actividad como pintar, jugar con bloques de madera, juegos de memoria... (figura 4).

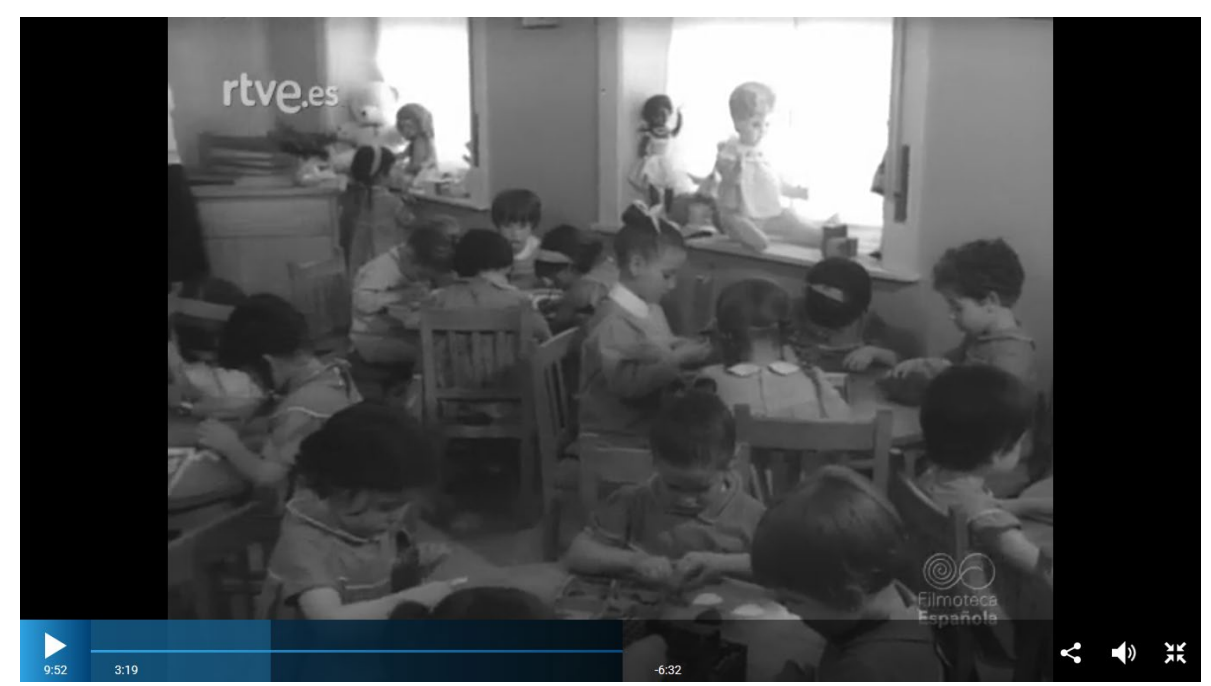

Figura 4. Niños y niñas jugando en sus pupitres. Fuente: (CFilmoteca Española y RTVE (2019). Tomada de Revista de Imágenes La semilla: una obra de Auxilio Social (01/01/1965).

Los niños que asistían a las guarderías y jardines maternales de Auxilio Social recibían, no solo instrucción, sino también nociones de gimnasia, atención médica (cada institución disponía de un despacho médico), higiene, alimentación y la inculcación de hábitos básicos, con el objetivo de que se convirtiesen en hombres y mujeres sanos, fuertes y autónomos. La 
higiene se practicaba de forma rigurosa, presidía el desarrollo de la vida de los niños y era considerada por el locutor como todo un espectáculo por la limpieza que reconfortaba a los niños, a pesar de que algunos sentían miedo al agua (Revista de Imágenes n. ${ }^{0} 611$, 01/01/1956).

La gimnasia era otro elemento esencial para favorecer el desarrollo de los niños (figura 5), aunque esta actividad solo fue mencionada en dos noticias. En una se resaltaba que el ejercicio y el sol abrían el apetito de los más pequeños (Revista de Imágenes, La semilla: una obra de Auxilio Social, 01/01/1965), y en la otra que las acogidas (250 niños y niñas que permanecían allí hasta los 7 años) en la Guardería Nuestra Señora de los Ángeles hicieron una demostración de ejercicios gimnásticos y de pasos de danza ante la princesa Sofía de Grecia y sus acompañantes (noticiario n.0 1111B, 20/04/1964). Por último, encontramos la hora de la comida donde los niños disfrutaban de los alimentos que les ofrecían en los comedores de las instituciones. "Alegres y luminosos comedores [componían] el ámbito donde se les [servía] la alimentación sana y adecuada" (Revista de Imágenes n. ${ }^{0}$ 611, 01/01/1956). El buen apetito de los acogidos era un tema principal de este tipo de noticias debido a la situación de pobreza y de hambruna que vivía España desde el final de la guerra.

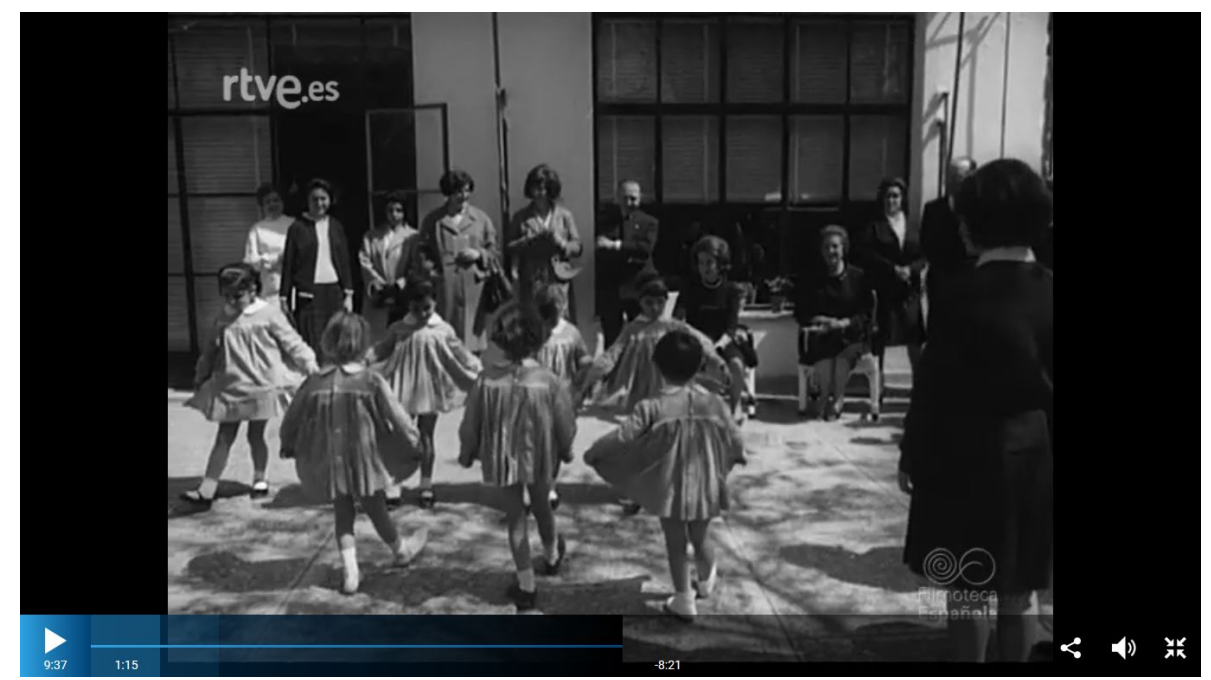

Figura 5. Niñas realizando una demostración de danza ante la princesa Sofía. Fuente: (CFilmoteca Española y RTVE (2019). Tomada de noticiario n. ${ }^{1} 111 \mathrm{~B}$ (20/04/1964).

Otro tema sobre el que giraban algunas de las noticias eran las inauguraciones y visitas a este tipo de centros. En el noticiario n. ${ }^{\circ}$ 702B (18/06/1956), Carmen Polo de Franco inauguró un albergue infantil en Corella y visitó la guardería, enclavada en esta misma localidad, para revisar todos sus detalles. Los noticiarios n. ${ }^{0} 887 A$ (04/01/1960) y n.o 993B (15/01/1962) mostraron la visita de Carmen Polo a diversas guarderías de Auxilio Social para entregar juguetes a los niños y niñas allí acogidos con motivo de la navidad. La esposa de Franco iba acompañada por diversas autoridades. En el número 887A (04/01/1960), los pequeños ejecutaron danzas en su honor, acto característico en las inauguraciones y visitas oficiales celebradas durante la dictadura (Molina, 2020). 
La educación preescolar vista a través de no-do (1943-1975): un proyecto benéfico-asistencial | María Dolores Molina-Poveda

\section{La obra de protección al niño huérfano 0 abandonado de Auxilio Social: los hogares infantiles}

Cuando los acogidos en la obra de Auxilio Social cumplían tres años eran trasladados de los hogares cuna a los hogares infantiles. A estos centros también accedían los niños de dicha edad que no podían ser cuidados por sus madres adecuadamente por hallarse en una situación de pobreza extrema. Los hogares infantiles eran instituciones que albergaban a los niños hasta los 7 años, separados por sexos y se diferenciaban de las guarderías y jardines maternales en que los asistidos se encontraban en régimen de internado. Sánchez y Hernández (2009) explican que la educación de los niños dependía de la ubicación de los diferentes hogares, es decir, si este se encontraba cerca de una zona urbana los acogidos asistían a la escuela pública, estatal, provincial, municipal o particular; en el caso de que los centros estuviesen alejados de la población, las maestras eran las encargadas de educar a los más pequeños realizando las actividades y utilizando los medios didácticos puestos en marcha en sus centros homólogos. Además, los hogares infantiles disponían de un departamento médico, de salas de estar y de salas de juegos. Estas últimas eran un elemento diferenciador para saber si el centro era para niños o niñas, pues en el primer caso había mesas para carpintero y talleres rudimentarios y en el segundo había cocinitas, mesas costureros, etc. (Boletín Auxilio Social n. ${ }^{6}$ 6, diciembre 1937, p. 4, citado en Orduña, 1996). Sin embargo, en No-Do no aparecía ninguna escena sobre las salas de juegos de los hogares infantiles de Auxilio Social.

En NO-DO solo encontramos dos reportajes, correspondientes a la sección de Revista de Imágenes, que mostraron los hogares infantiles. El número 611 de Revista de Imágenes (01/01/1956) explicaba cómo era la vida de los niños acogidos en un hogar infantil, concretamente en el hogar infantil femenino situado en los Montes de Montcabrer (Alicante). Este centro albergaba a niñas de entre 3 y 8 años en un ambiente atractivo que les permitía olvidar las angustias, las penurias y las preocupaciones prematuras que no correspondían a su edad. El locutor no cesaba de repetir esta idea, pues más adelante volvía a enfatizar sobre la admirable labor que Auxilio Social realizaba desde que acogía a las madres en los centros de maternología hasta la acogida de los niños en estos hogares donde se devolvía "el optimismo y la alegría a las pequeñas [y a los pequeños] que crecen al amparo de la obra".

Los hogares de Auxilio Social atendían tanto a los niños huérfanos como con familias en situación de pobreza, y los vestían, alimentaban y cuidaban a través del "personal rector oportuno y también de guardadoras y empleados subalternos deliberadamente capacitados para esta delicada misión" (Revista de Imágenes n. $\left.{ }^{\circ} 611,01 / 01 / 1956\right)$. La imagen que NO-DO mostraba a todos los españoles de niños bien aseados, alimentados, cuidados, que jugaban, reían y disfrutaban en "un ambiente atractivo que les ayuda a olvidar las angustias y preocupaciones prematuras, que de otro modo tendrían en una atmósfera de penuria" (Revista de Imágenes n. $\left.{ }^{\circ} 611,01 / 01 / 1956\right)$, chocaba con la realidad de la mayoría de las familias y, como indican González (2009) y Cenarro (2009), con la realidad de los propios hogares de Auxilio Social.

En el hogar infantil de los Montes de Montcabrer había una maestra nacional. Su función era iniciar a las niñas en la enseñanza a través de una "pedagogía desarrollada con paciencia y cariño" (Revista de Imágenes n. 0 611, 01/01/1956) para favorecer la captación de la atención de las alumnas. Las imágenes mostraban a las niñas en un aula mientras la maestra daba la lección. Vemos como algunas de ellas escribían en pizarrines o en libretas. El aula 
contaba con dos pizarras y en una de ellas una niña se encontraba resolviendo un problema de cálculo. Los pupitres eran para dos alumnas y sobre la otra pizarra, situada detrás de la mesa de la maestra, había un crucifijo. Este no era el único elemento o signo religioso en el centro, pues NO-DO mostró a las niñas rezando antes de empezar a comer (figura 6). La hora del recreo era un momento de expansión y de disfrute para las pequeñas que "jugaban alegres" en los columpios, toboganes, con muñecos o con las cuidadoras. Los paseos por el monte era otra de las actividades principales y características de estos centros, según No-DO, ya que se fomentaba el ejercicio físico y el que las niñas respirasen aire puro y fresco (figura 7).

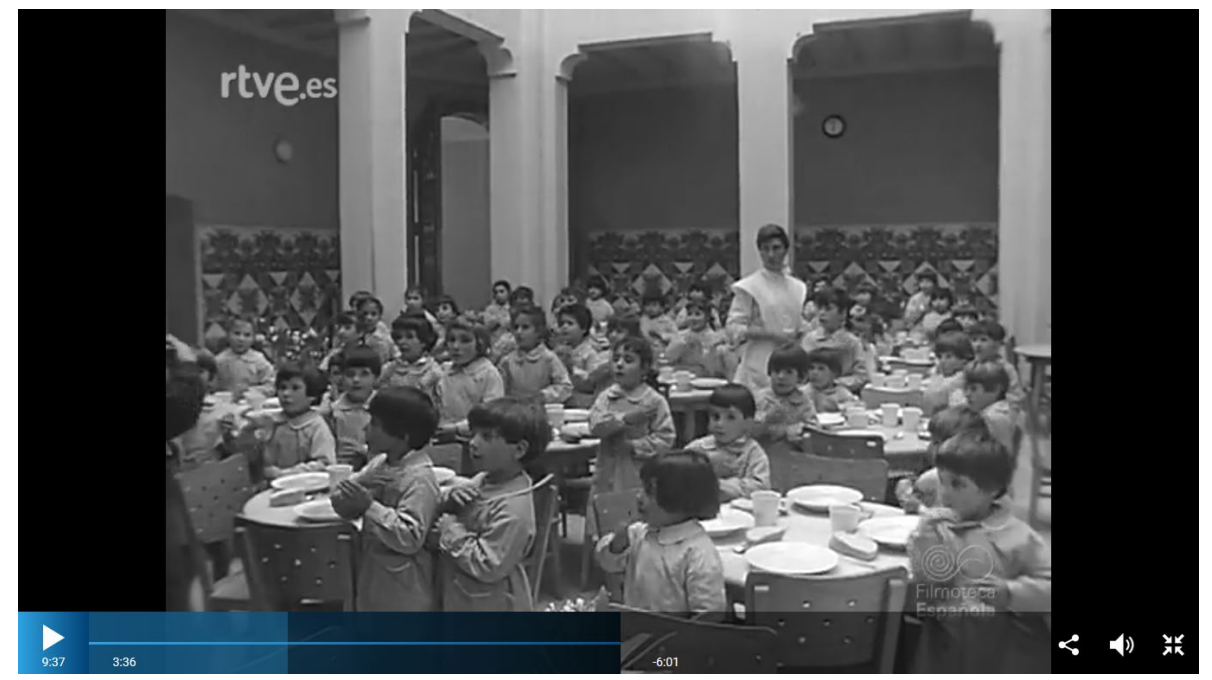

Figura 6. Niñas del hogar infantil de los Montes de Montcabrer rezando antes de comer. Fuente: (CFilmoteca Española y RTVE (2019). Tomada de Revista de Imágenes n.0 611 (01/01/1956).

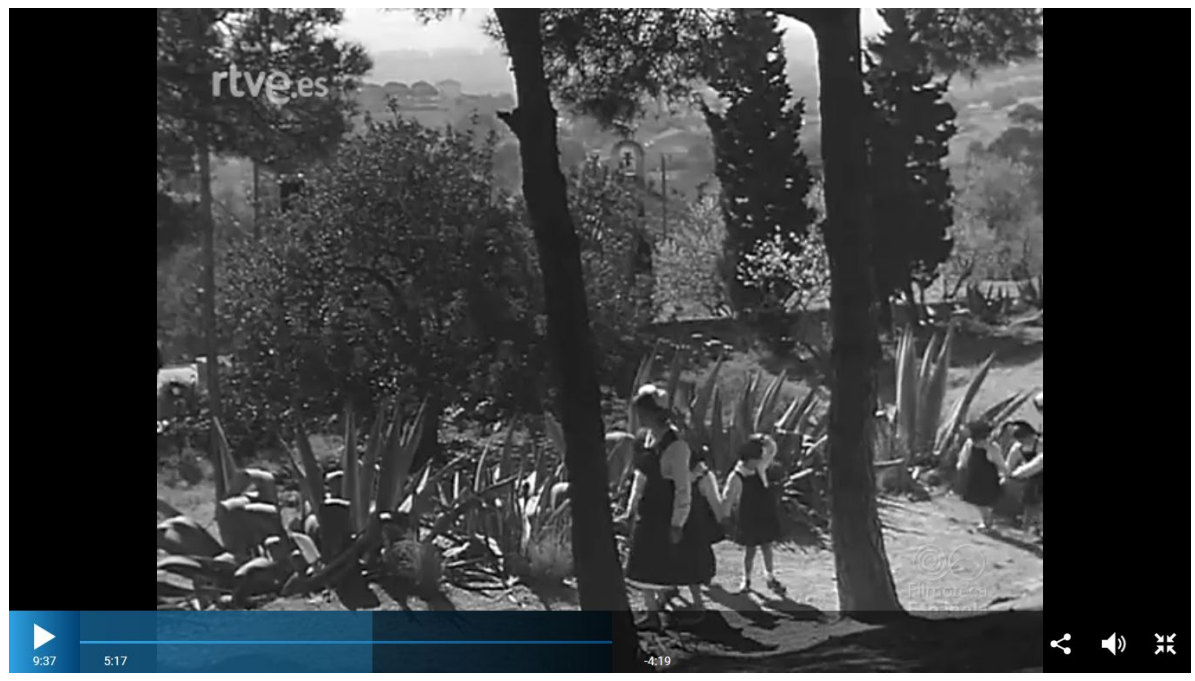

Figura 7. Niñas del hogar infantil de los Montes de Montcabrer paseando por el monte. Fuente: CFilmoteca Española y RTVE (2019). Tomada de Revista de Imágenes n. $611(01 / 01 / 1956)$. 
Anteriormente hemos mencionado que se afirmaba que estos centros se regían por pedagogías basadas en Montessori, Froebel y Decroly, aunque en las imágenes de este número apreciamos que la metodología imperante en el aula era la tradicional, es decir, niñas sentadas en sus pupitres resolviendo cuentas o problemas, o leyendo y escribiendo en libretas pautadas. Si revisamos las normas de educación e instrucción dictadas por la Asesoría Nacional de Pedagogía vemos que en la etapa de 5 a 7 años se incluían aprendizajes memorísticos lo que nos lleva a pensar que, al final, una vez superados los 5 años, el juego pasaba a ser un elemento secundario en el aprendizaje de las niñas y de los niños a pesar de que No-Do lo seguía nombrando como un elemento central en estos centros, aunque no podemos afirmar esta hipótesis, pues los números cinematográficos que NO-DO emitió sobre estos hogares son escasos (figura 8).

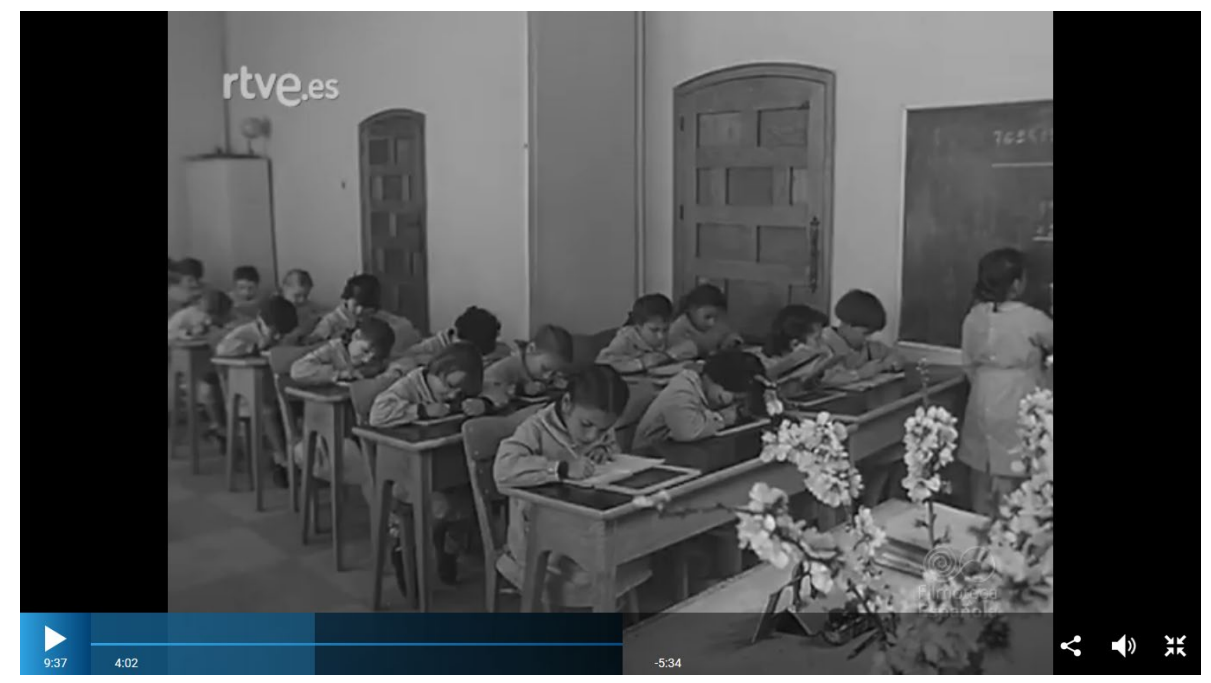

Figura 8. Niñas del hogar infantil de los Montes de Montcabrer resolviendo problemas de cálculo. Fuente: CFilmoteca Española y RTVE (2019). Tomada de Revista de Imágenes n. ${ }^{\circ} 611$ (01/01/1956).

El siguiente reportaje en el que se mencionan los hogares infantiles es el titulado La semilla: una obra de Auxilio Social (Revista de Imágenes, 01/01/1965). El locutor solo informaba a los espectadores de que los niños que habían visto en el hogar cuna eran "ya unos señorones de tres años" y que "los hogares infantiles de niñas o de niños descubren la euritmia a través de los juegos" (Revista de Imágenes, La semilla: una obra de Auxilio Social, 01/01/1965). Volvemos a encontrar una mención al desarrollo físico y a la adquisición de movimientos armoniosos a través del juego (figura 9). 

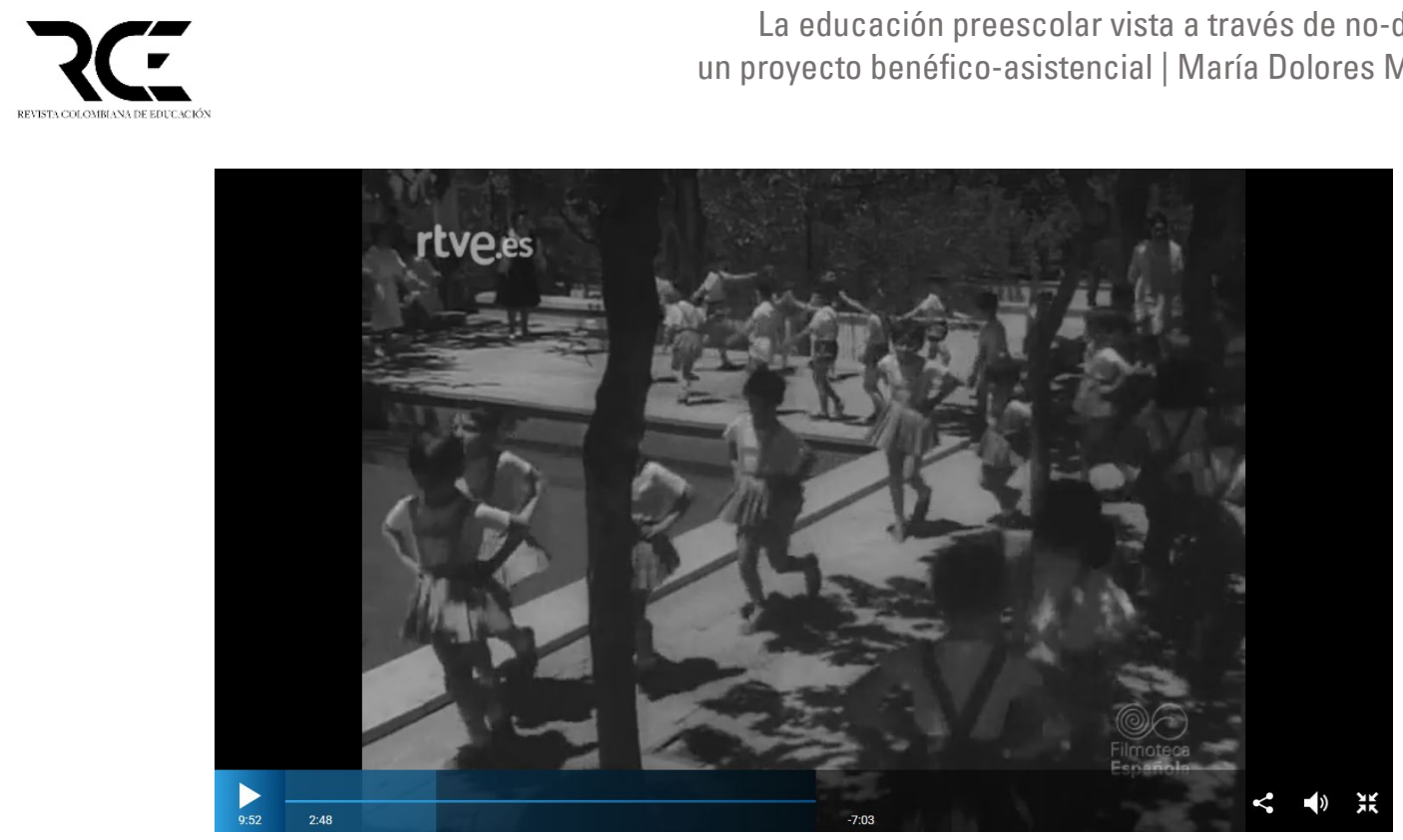

Figura 9. Niños y niñas de un hogar infantil de Auxilio Social "descubriendo la euritmia a través del juego". Fuente: CFilmoteca Española y RTVE (2019). Tomada de Revista de Imágenes, La semilla: una obra de Auxilio Social (01/01/1965).

\section{Conclusiones}

La instauración de la dictadura franquista en España en 1939 supuso para la etapa de preescolar la paralización de las medidas educativas impulsadas en los años precedentes. La concepción que el nuevo régimen tenía de la familia invisibilizó a la mujer trabajadora e impulsó la figura del ama de casa que cuidaba de los hijos al menos hasta que alcanzaban la edad obligatoria para ir al colegio. A partir de la década de los 60, el número de trabajadoras aumentó, aunque Millán et al. (2015) destacan que el número de mujeres que trabajaban fuera del hogar no llegaba a los dos millones y medio produciéndose un mayor crecimiento en la década de los 70.

Desde los años 40 hasta la entrada de la democracia (1975), pocas mujeres tenían un trabajo remunerado fuera del hogar, siendo una variable determinante el estado civil, pues más de 80 por ciento de las trabajadoras españolas de esas décadas eran solteras. (Millán et al., 2015, p. 199)

Al casarse, lo bien visto socialmente era abandonar su trabajo para cuidar de su marido y de sus hijos, aunque esta opción solo era accesible para las mujeres de clase media y alta (Sanchidrián, 2008), ya que las de clase baja debían permanecer en su puesto laboral para poder mantener a su familia. Auxilio Social y las cajas de ahorros (entre otras entidades) impulsaron este tipo de centros en algunas zonas rurales y obreras donde más demanda había de este nivel educativo por existir un porcentaje más elevado de mujeres trabajadoras, aunque las políticas sociales fueron insuficientes de forma que el trabajo femenino pudo mantenerse gracias al apoyo familiar que fue el que compensó la escasez de centros de atención a los menores. 
NO-DO presentó una gran variedad de noticias desde 1943 hasta 1975, aunque el número de noticias que proyectó sobre las guarderías y jardines maternales fue escaso ${ }^{3}$. Sin embargo, esta muestra puede ser considerada como representativa si tenemos en cuenta la desidia presentada por el régimen hacia este nivel educativo, a pesar de ciertas demandas manifestadas por parte de la sociedad española, y de que a partir de la década de los 60 se comenzase a prestar más atención a la mujer trabajadora. La cantidad de números emitidos por NO-DO que mostraron las guarderías, los jardines maternales y los hogares infantiles comenzó a aumentar en la década de los sesenta, cuando el trabajo femenino se hizo más visible en España. Destaca también que la obra asistencial impulsada por las cajas de ahorros fue proyectada en los noticiarios y reportajes cinematográficos franquistas a partir de 1962 encontrando solo tres números, aunque extensos, que trataban este tema. Las guarderías y los jardines maternales estaban situados en Bermejo y en Andalucía y, más concretamente, en zonas rurales, pesqueras e industriales. El número de centros mostrados por NO-Do era insuficiente para estas ubicaciones.

Esto mismo sucedía con las guarderías creadas por Auxilio Social o por otras entidades que se encontraban en zonas industriales y obreras, aunque la mayoría de las noticias y reportajes que los mostraron omitían la localidad donde se ubicaban estos centros. No obstante, NO-DO destacó en algunos de sus números que las obras de Auxilio Social y de las cajas de ahorros tenían una amplia red de centros, por lo que el número de guarderías pudo ser mayor al mostrado o lo decían en un afán para enaltecer la labor del régimen, aunque luego esos datos no fuesen ciertos.

Se afirmaba en el NO-DO que en las guarderías, jardines maternales y hogares infantiles se atendía a los niños según las normas pedagógicas más avanzadas, pero sin explicar en que consistían dichas normas. No obstante, las imágenes que se transmitieron sobre estos centros solo mostraron a los niños jugando en el patio o en las clases, por lo que las imágenes presentadas ni siquiera dejaron constancia de que en esos centros fuera cierta la implantación de esas normas pedagógicas más avanzadas de las que hablaba el locutor. No obstante, a partir de la década de los 60 y de los 70, las locuciones de los números de NO-Do si comenzaron a destacar el juego como un elemento educativo y pedagógico que permitía el desarrollo y el aprendizaje del niño. Además, destacaban las muestras de cariño que las maestras y cuidadoras daban a los pequeños. Con estas actitudes y acciones se pretendía recrear el clima de hogar y cariño maternal que el niño tendría que recibir en su casa y del que carecía al estar su madre trabajando. Este hecho puede ser una muestra del carácter propagandístico de NoDo al utilizar estas situaciones como un contraejemplo de cómo debería actuar y comportarse la mujer, es decir, su deber era cuidar a sus hijos, su casa y a su marido y no trabajar fuera del hogar con todas las consecuencias que esto conllevaba como, por ejemplo, que el amor, los mimos y la educación que tenía que impartir la madre tuviese que hacerlo un "extraño".

En definitiva, NO-Do mostró estas guarderías, jardines maternales y hogares infantiles como una extensión del hogar donde el niño recibía los mismos cuidados y atenciones que en su casa, además de poder aprender los conocimientos básicos de su edad jugando y divirtiéndose. Sin embargo, conforme los pequeños iban creciendo podemos comprobar cómo los métodos iban cambiando. Estos métodos se caracterizaban por privilegiaba la memorización y la disciplina y no tanto el movimiento, como en los años anteriores a los cinco años. Sin embargo, es importante tener en cuenta que No-Do, como buen medio propagandístico del régimen, mostraba imágenes que parecían más una recreación que una situación cotidiana de un aula o centro educativo, lo que provocaba que estas imágenes y

\footnotetext{
${ }^{3}$ NO-Do proyectó, entre sus cinco secciones, un total de 6029 números cinematográficos (4011 Noticiarios; 216 Documentales en Blanco y Negro; 495 Documentales en Color; 88 Imágenes del Deporte; y 1219 Revista de Imágenes).
} 
locuciones fuesen poco realistas y que presentasen situaciones un tanto idílicas que resultaban, y resultan, difíciles de creer.

\section{Referencias}

Batres, A. (2016). La concepción de la Educación Infantil en España y su influencia en la formación de su profesorado. RELAdEI 5.4. Revista Latinoamericana de Educación Infantil, 5(4), 106-118. http://ojs3usc.devxercode.es/index.php/reladei/article/view/4957

Carreño, M. (2002). La segunda mitad del siglo Xx: análisis sociohistórico y educativo (19501990). En S. San Román Gago, M. Carreño, M. Colmenar y T. Rabazas (coords.), La maestra en el proceso de cambio social de transición democrática: espacios histórico generacionales (pp. 87-126). Instituto de la Mujer.

Cenarro, A. (2009). Los niños del auxilio social. Espasa.

Filmoteca Española y Radio Televisión Española (RTVE). (2019). Noticiarios y documentales cinematográficos (NO-DO). http://www.rtve.es/alacarta/videos-audios/noticiarios-nodo/

González, F. (2009). Niños invisibles en el cuarto oscuro: experiencias en el auxilio social del franquismo. Editorial Tébar.

Hernández, D. (2012). La investigación histórica. Conceptos generales. Historia, teoría y praxis histórica. En M. Peréx (ed.), Métodos y técnicas de investigación histórica I (pp. 1345). Universidad Nacional de Educación a Distancia (UNED).

Jefatura del Estado. (1945). Ley de 17 de julio de 1945 sobre Educación Primaria. Boletín Oficial del Estado, $199, \quad$ pp. https://www.boe.es/datos/pdfs/BOE//1945/199/A00385-00416.pdf

Jefatura del Estado. (1970). Ley 14 de 1970, de 4 de agosto, General de Educación y Financiamiento de la Reforma Educativa. Boletín Oficial del Estado, 187, pp. 12.52512.546. https://www.boe.es/boe/dias/1970/08/06/pdfs/A12525-12546.pdf

Martín, R. (2006). Los medios de comunicación social como formas de persuasión durante el primer franquismo. En J. Delgado (coord.), Propaganda y medios de comunicación en el primer franquismo (1936-1959) (pp. 15-28). Universidad de La Rioja.

Martínez, A. (2014). Las cajas de ahorros en el Sistema Financiero español: ahorro y marco institucional, 1839-1959. En J. Gutiérrez y F. Martínez (eds.), El sistema financiero en la España contemporánea (pp. 211-274). Universidad de Cantabria.

Millán, M., Santos, M. y Pérez, L. (2015). Análisis del mercado laboral femenino en España: evolución y factores socioeconómicos determinantes del empleo. Papeles de Población, 21(84), 197-225. http://www.scielo.org.mx/pdf/pp/v21n84/v21n84a8.pdf

Ministerio de Información y Turismo. (1975). Orden de 22 de agosto de 1975 acordada en Consejo de Ministros por la que se regula la proyección de cortometrajes en las salas de exhibición cinematográficas y se suprime la obligatoriedad de proyección del Noticiario Cinematográfico Español "NO-DO". Boletín Oficial del Estado, 225, p. 19.870. https://www.boe.es/boe/dias/1975/09/19/pdfs/A19870-19870.pdf 
Ministerio de Trabajo. (1948). Orden de 26 de octubre de 1948 por la que se define y regula la obra benéfico-social de las Cajas Generales de Ahorro Popular. Boletín Oficial del Estado, 306, p. 5034. https://www.boe.es/datos/pdfs/BOE//1948/306/A05034-05034.pdf

Molina, M. (2020). El no-do como medio de construcción de la identidad femenina. Historia y Memoria de la Educación, (12), 239-270. https://doi.org/10.5944/hme.12.2020.26071

Molina, M. y Sanchidrián, C. (2020). La formación profesional vista a través de no-do (19431981): propaganda e ideología en un pasado reciente. Espacio, Tiempo y Educación, 7(2), 135-156. http://dx.doi.org/10.14516/ete. 251

Monés i Pujol-Busquets, J. (1991). La educación preescolar en España desde el final de la Guerra Civil hasta los años 60. Historia de la Educación: Revista Interuniversitaria, (10), 155-186. 0267/article/viewFile/6917/6898

Montesino, P. (1840). Manual para los maestros de escuelas de párvulos. Imprenta Nacional.

Orduña, M. (1996). El auxilio social (1936-1940). La etapa fundacional y los primeros años. Escuela Libre Editorial. https://biblioteca.fundaciononce.es/sites/default/files/publicaciones/documentos/el_auxili o_social_1936-1940.pdf

Paz, M. y Sánchez, M. (1999). La historia filmada: Ios noticiarios cinematográficos como fuente histórica. Una propuesta metodológica. Filmhistoria online, 9(1), 17-33. http://revistes.ub.edu/index.php/filmhistoria/article/view/12366

Pérez, F. (2010). La atención pública a los menores almerienses (1936-1970). Universidad de Almería.

Roca, I y Girona, J. (2005). Los (no) lugares de las mujeres durante el franquismo: el trabajo femenino en el ámbito público y privado. Gerónimo de Uztariz, (21), pp. 81-99. https://dialnet.unirioja.es/servlet/articulo?codigo $=2173584$

Rodríguez Martínez, S. (1999). El NO-DO: catecismo social de una época. Editorial Complutense.

Rodríguez Mateos, A. (2008). Un franquismo de cine: la imagen política del régimen en el noticiario NO-DO (1943-1959). Rialp.

Ruiz, J. (2010). Pablo Montesino y las primeras escuelas de párvulos en España. En C. Sanchidrián y J. Ruiz Berrio (coords.), Historia y perspectiva actual de la educación infantil (pp. 91-111). Graó.

Sánchez, L. (2008). Auxilio social y la educación de los pobres: del franquismo a la Democracia. Foro de Educación, 133-166. https://dialnet.unirioja.es/servlet/articulo?codigo=2906847

Sánchez, L., y Hernández, J. (2009). La educación política de los Hogares de Auxilio Social en el franquismo. En M. Berruezo y S. Conejero (coords.), El largo camino hacia una educación inclusiva: la educación especial y social del siglo XIX a nuestros días: XV Coloquio de Historia de la Educación (pp. 427-438). Universidad Pública de Navarra. https://dialnet.unirioja.es/servlet/articulo?codigo=2964136

Sanchidrián, C. (1991). Funciones de la escolarización de la infancia: objetivos y creación de las primeras escuelas de párvulos en España. Historia de la Educación, (10), 63-87. http://revistas.usal.es/index.php/0212-0267/article/viewFile/6913/6894 
Sanchidrián, C. (2008). Estudios universitarios y ejercicio profesional de las mujeres en el franquismo. En C. Jiménez y G. Pérez (coords.), Educación y género. El conocimiento invisible (pp. 217-248). UNED, Editorial Tirant Lo Blanch.

Sanchidrián, C. (2009). La extensión de la escolaridad temprana como síntoma y resultado del cambio educativo y social. En M. Berruezo y S. Conejero (coords.), El largo camino hacia una educación inclusiva: la educación especial y social del siglo XIX a nuestros días (vol. 2, pp. 451-462). UPNA. https://dialnet.unirioja.es/servlet/articulo?codigo=2964142

Sanchidrián, C. (2015). The Role of the State and the Church in the Development of Early Childhood Education in Spain (1874-1975). En H. Willekens, K. Scheiwe y K. Nawrotzki (eds.), The Development of Early Childhood Education in Europe and North America (pp. 92-111). Palgrave MacMillan.

Secretaría General del Movimiento. (1942). Orden de 17 de diciembre de 1942. Disponiendo la proyección obligatoria y exclusiva del Noticiario Cinematográfico Español y concediendo la exclusividad absoluta de reportajes cinematográficos a la entidad editora del mismo, Noticiarios y Documentales, Cinematográficos "no-do". Boletín Oficial del Estado, 356, p. 10.444. https://www.boe.es/datos/pdfs/BOE//1942/356/A10444-10444.pdf

Sureda, B. (2010). La modernización de la escuela infantil en Cataluña. En C. Sanchidrián y J. Ruiz (coords.), Historia y perspectiva actual de la educación infantil (pp. 245-265). Graó.

Tranche, R. y Sánchez-Biosca, V. (2018). NO-DO, el tiempo y la memoria. Cátedra.

Valiente, C. (2010). Las políticas de cuidado de los niños durante el franquismo. En L. Prieto (ed.), Encuadramiento femenino, socialización y cultura en el Franquismo (pp. 233-249). Centro de Ediciones de la Diputación de Málaga. 